\title{
La ancianidad en el Derecho Constitucional argentino(*)
}

\section{Old age in Argentine Constitutional Law}

\author{
Mariano Horacio Novelli(**) \\ Universidad Nacional de Rosario
}

\begin{abstract}
Resumen: La problemática de la ancianidad no ha sido históricamente objeto de interés del debate jurídico. Recién en los últimos lustros ha comenzado a ser abordada esta compleja etapa vital, especialmente desde el Derecho Civil, el Derecho Penal y la lusfilosofía. Empero, son aún escasos los estudios centrados en la perspectiva constitucional y en los derechos subjetivos de las personas mayores. Tal perfil reviste el presente trabajo, que efectúa un análisis detallado y comparativo de los plexos normativos de la máxima jerarquía en la República Argentina. Destaca que el anciano es un individuo débil, en concordancia con los tiempos postmodernos, que frecuentemente resulta víctima de violencia económica, estructural, física, psíquica y sexual. Enfatiza asimismo que el Derecho constituye un instrumento de sumo valor para subsanar dicha debilidad, por medio del fortalecimiento de las condiciones de vida y status de las personas mayores.
\end{abstract}

Palabras Clave: Ancianidad - Derecho Constitucional - Derechos - Debilidad Jurídica - Violencia - Constitución Nacional Argentina - Constituciones Provinciales Argentinas

\begin{abstract}
Historically, the problem of old age has not been an object of interest to the legal debate. Only in recent years, this complex stage of life has begun to be addressed, especially by Civil Law, Criminal Law and Philosophy of Law. However, there are still few studies which focus on the constitutional perspective and the rights of the elderly. That is the profile of the present work, which carries out a detailed and comparative analysis of the regulations of the highest hierarchy in Argentina. It emphasizes that, in accordance with postmodern times, the elderly person is a weak individual
\end{abstract}

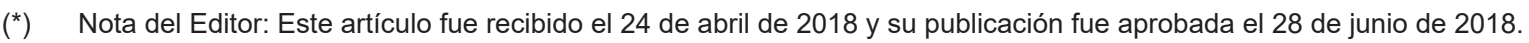

${ }^{* *}$ ) Profesor en la Facultad de Derecho de la Universidad Nacional de Rosario (Argentina). Secretario en el Poder Judicial de la Provincia de Santa Fe. Becario Fulbright del De-partamento de Estado de los Estados Unidos. Premio "Corte Suprema de Justicia de la Provincia de Santa Fe" y "Corte Suprema de Justicia de la Nación”. Correo electróni-co: mnovelli@unr. edu.ar 


\section{La ancianidad en el Derecho Constitucional argentino Old age in Argentine Constitutional Law}

who frequently becomes a victim of economic, structural, physical, psychological and sexual violence. It also stresses that Law is an instrument of great value to overcome this weakness, by strengthening the living conditions and status of the elderly.

Keywords: Old Age - Constitutional Law - Rights - Legal Weakness - Violence - Argentine National Constitution - Argentine Provincial Constitutions

Sumario: 1. Introducción_2. Los derechos constitucionales de los ancianos en Argentina_2.1. La Constitución Nacional_2.1.1. Constitución de 1853_2.1.2. Reforma de 1860_2.1.3. Constitución de 1949_2.1.4. Reforma de 1957.2.1.5. Reforma de 1994_2.2. Las constituciones provinciales_2.2.1. Cuestiones generales_2.2.2. Ciclos del Derecho Constitucional provincial argentino_2.2.3. Tratamiento de la ancianidad en las constituciones provinciales_ 3. Conclusiones.

\section{Introducción}

La reflexión sobre los derechos constitucionales de los ancianos representa un deber que se impone, por indispensable, en el debate jurídico contemporáneo. Sin embargo, si indagamos en la doctrina, advertiremos que durante largo tiempo el tema no fue objeto de atención ${ }^{(1)}$.

La posición social de las personas mayores no ha sido la misma a lo largo de la historia (Dabove 2002; Minois 1989; Granjel 1991; Alba 1992; Sagrera 1992; Gracia Guillén 1995); en ciertas ocasiones han sido favorecidas y en otras, minusvaloradas (Morelli 1999, 36) 2 .
Específicamente en el tiempo de la postmodernidad, el anciano constituye un individuo débil, sometido a una triple situación de debilidad:

"la dinámica jurídico social torna vulnerable al viejo, en tanto lo estereotipa y lo constriñe en su ámbito de actuación. El sistema normativo lo debilita por no ofrecerle completamente un marco de protección jurídica adecuado a su naturaleza. Y también lo debilitan los valores jurídicos imperantes, cada vez que no reconocen suficientemente a la persona anciana como fin en sí" (Novelli 2008, 751).

Las personas mayores son frecuentemente víctimas de diversas clases de violencia: económica, estructural, física, psíquica y sexual. Y esto no se produce por azar, sino que es una palmaria consecuencia de sus escasas posibilidades de defensa efectiva.

En dicho contexto, se impone que la debilidad del anciano sea subsanada, o cuanto menos menguada, por medio del fortalecimiento de sus condiciones de vida y status ${ }^{(3)}$. A tal efecto, el Derecho se erige como un instrumento de sumo valor, especialmente con el reconocimiento de derechos en el plano constitucional, temática que abordaremos seguidamente.

(1) En efecto, el Derecho de la Ancianidad fue enriquecido durante la década de 1990 desde la Filosofía del Derecho, el Derecho Civil y el Derecho Penal, pero no así desde el Derecho Constitucional. De allí que hayamos decidido hace varios años profundizar este aspecto, lo cual dio como resultado nuestro estudio Los derechos constitucionales de los ancianos en la Argentina, publicado en Buenos Aires por Editorial Dunken y la Fundación para las Investigaciones Jurídicas en 2006 (obra declarada de Interés Legislativo por la Honorable Cámara de Diputados de la Nación el 7 de noviembre de 2007 y por la Honorable Cámara de Diputados de la Provincia de Buenos Aires el 4 de diciembre de 2007). Sobre dicha base partimos para elaborar el presente trabajo.

(2) Empero, no es unánime la idea de que la consideración hacia la vejez ha ido oscilando, sino que hay quienes sostienen que el transcurso de la historia ha operado en aquélla un constante declive. Se ha afirmado, en este último sentido, que "la estimación social del anciano ha ido decreciendo con el paso del tiempo, de modo que fue inmensa en las culturas primitivas, y ha ido perdiendo puestos según ha ido pasando el tiempo" (Gracia Guillén 1995, 15).

(3) Es unánime en doctrina la idea del anciano como sujeto merecedor de "particular protección" (Ciuro 1992, 35) o "digno de especial deferencia" (Méndez 1983, 313). La estimamos profundamente acertada, pues permite orientar el progreso del Derecho con miras a las necesidades reales de los mayores. 
Mariano Horacio Novelli

\section{Los derechos constitucionales de los ancianos en Argentina}

\subsection{La Constitución Nacional}

A nivel de la Constitución Nacional argentina, la consagración de los derechos de los ancianos ha sido progresiva. No obstante, es menester admitir el creciente reconocimiento confluente que al Derecho de la Ancianidad han ido brindando no sólo el Derecho Constitucional sino también el Derecho Internacional (Ciuro 1995, 10).

\subsubsection{Constitución de 1853}

El tema de la población de edad avanzada como merecedora de un tratamiento particular, lógicamente no se planteó en la Constitución Nacional de 1853, fundada en los postulados liberales y tributarios de la filosofía de la llustración. Sin embargo, ello no excluye que, al consagrarse el principio de igualdad en el artículo 16, se haya establecido una garantía de preservación de un grupo pasible de ser afectado en sus derechos en razón de la edad.

\subsubsection{Reforma de 1860}

Entre las enmiendas formuladas a la Constitución en $1860^{(4)}$, resulta de interés la incorporación del artículo 33, que se refiere a los "derechos no enumerados"(5).

Mucho se ha debatido acerca de las implicancias de este concepto, y por ello parece necesario retroceder en el tiempo e ir a las fuentes, para descubrir su auténtico alcance. Según el despacho de la Convención Examinadora de la Constitución de 1853, son derechos que nacen de la propia naturaleza y "forman el derecho natural de los individuos y de las sociedades". En la Asamblea del Estado de Buenos Aires, Sarmiento expresó que son derechos "superiores a la Constitución", grabados "en la conciencia universal de la humanidad” (Sagüés 1997, 2:246).

Se advierte así que los derechos no enumerados, contrariamente a lo que se desprendería de la literalidad del artículo 33 -que versa sobre aquellos que nacen "de la soberanía del pueblo y de la forma republicana de gobierno"-, no son sólo de índole política, sino que pueden ser de cualquier clase. La disposición, de tal manera, debe comprenderse armónicamente en el marco del sistema que la contiene, lo cual exige que se la interprete "como afincada en el personalismo humanista que hace de filosofía o atmósfera ideológica de la constitución" (Bidart 1995, 471).

Partiendo de los valores, principios y derechos constitucionales explícitos, hay que tener en cuenta la transformación progresiva de las necesidades humanas y las valoraciones sociales contemporáneas (Bidart 1995, 472), "por la sencilla razón de que deben respetarse, promoverse y adjudicarse todos los bienes que en cada situación concreta le son precisos al ser humano para emplazar su vida personal con dignidad en la convivencia societaria" (Bidart 1998, 102).

De allí que deben entenderse contemplados en el artículo 33 todos los derechos de los hombres, e incluso de los pueblos, que no fueron considerados expresamente cuando se sancionó la Constitución, pero que se compadecen con su espíritu desde una óptica actual.

Por todo lo dicho, puede sostenerse con sólidos fundamentos que, a partir de la Reforma de 1860, los derechos de los ancianos se hallan implícitos en la Carta Magna argentina, dado los especiales valores que les hacen de substractum.

(4) Las modificaciones fueron propuestas por la Convención de la Provincia de Buenos Aires (que sesionó desde el 5 de enero hasta el 12 de mayo de 1860) y aceptadas por la Convención Nacional ad hoc (que se celebró en Santa Fe, entre los días 22 y 25 de septiembre de 1860).

(5) Textualmente, dice: "Las declaraciones, derechos y garantías que enumera la Constitución, no serán entendidos como negación de otros derechos y garantías no enumerados, pero que nacen del principio de la soberanía del pueblo y de la forma republicana de gobierno". 


\section{La ancianidad en el Derecho Constitucional argentino Old age in Argentine Constitutional Law}

\subsubsection{Constitución de 1949}

La Constitución de 1949, que sustituyó a la de 185360 , incorporó al Derecho argentino los preceptos del constitucionalismo social y tuvo un basamento ideológico solidarista.

La enumeración de los "derechos de la ancianidad" fue minuciosamente expuesta en el apartado III de su artículo 37 , que procuró superar ciertas prácticas de la seguridad social(6) y entender a los mayores desde una perspectiva comprensiva de todas las dimensiones de su vida (Novelli 2006, 46-47).

Tal precepto reza:

“De la ancianidad.

1.- Derecho a la asistencia: Todo anciano tiene derecho a su protección integral, por cuenta y cargo de su familia. En caso de desamparo, corresponde al Estado proveer a dicha protección, ya sea en forma directa o por intermedio de los institutos y fundaciones creadas, o que se crearen con ese fin, sin perjuicio de la subrogación del Estado o de dichos institutos, para demandar a los familiares remisos y solventes los aportes correspondientes.

2.- Derecho a la vivienda: El derecho a un albergue higiénico, con un mínimo de comodidades hogareñas es inherente a la condición humana.

3.- Derecho a la alimentación: La alimentación sana y adecuada a la edad y estado físico de cada uno, debe ser contemplada en forma particular.

4.- Derecho al vestido: El vestido decoroso y apropiado al clima complementa el derecho anterior.

5.- Derecho al cuidado de la salud física: El cuidado de la salud física de los ancianos ha de ser preocupación especialísima y permanente.
6.- Derecho al cuidado de la salud moral: Debe asegurarse el libre ejercicio de las expansiones espirituales, concordes con la moral y el culto.

7.- Derecho al esparcimiento: Ha de reconocerse a la ancianidad el derecho de gozar mesuradamente de un mínimo de entretenimientos para que pueda sobrellevar con satisfacción sus horas de espera.

8.- Derecho al trabajo: Cuando el estado y condiciones lo permitan, la ocupación por medio de la laborterapia productiva ha de ser facilitada. Se evitará así la disminución de la personalidad.

9.- Derecho a la tranquilidad: Gozar de tranquilidad, libre de angustias y preocupaciones, en los años últimos de existencia, es patrimonio del anciano.

10.- Derecho al respeto: La ancianidad tiene derecho al respeto y consideración de sus semejantes".

Un aspecto relevante, señalado como fundamento de la tutela a los ancianos, fue expuesto por algunos de los constituyentes de 1949, que se refirieron a la necesidad de impulsar la protección de la vejez por la dignidad de la condición humana y no por el carácter de trabajador que hubiera revestido el beneficiario de estas políticas (en particular la jubilación). Se dejaba de lado, ergo, la óptica que había primado hasta entonces, de compensación por lo aportado en el tiempo de actividad laboral previo al retiro.

En este sentido, expresó en una de sus intervenciones el convencional Rodolfo Valenzuela:

(6) Hasta entonces, la vejez era solamente visualizada a los efectos de su cobertura previsional. 
Mariano Horacio Novelli

"No encontraremos antecedentes extranjeros de las normas cuya inclusión constitucional propugnamos. Siempre fue reconocida por la legislación la necesidad de proteger a los ancianos, desde la declaración de los derechos del hombre de 1789, hasta la Constitución cubana de 1940, para citar uno de los últimos cuerpos constitucionales con sentido social. Pero esa protección se busca a manera de compensación de lo que se le debe a un trabajador, cuya facultad de producir se ha extinguido cuando aquél ya no es socialmente útil. (...) Nosotros (...) vamos más lejos, porque el sentido que nos inspira no está contagiado en consideración materialista alguna, remota, mediata o inmediata, sino por el deseo de imponer la justicia social y de extenderla a todos los factores humanos integrantes de la sociedad, válidos o inválidos, económicamente útiles o forzosamente desamparados e inútiles" (Convención Nacional Constituyente 1949, 319-320).

Quedó de tal modo sentado un criterio innovador en la materia, tanto en el ámbito nacional como mundial, que el antedicho convencional no vaciló en denominar "doctrina argentina de los derechos de la ancianidad" (Convención Nacional Constituyente 1949, 320). ${ }^{(7)}$

\subsubsection{Reforma de 1957}

En 1957, tras la derogación de la Constitución de $1949^{(8)}$ y la reimplantación de la de $1853-60^{9}$, se incorporó a esta última el artículo 14 bis, cuyo tercer párrafo receptó ciertos derechos vinculados a los ancianos, pero nuevamente desde la perspectiva previsional. Se perdió, de esa forma, la comprensión integral de la persona mayor como beneficiario de protección por su sola condición, que se había obtenido con el texto sancionado ocho años antes.

La nueva disposición, en su parte pertinente, señala:

"El Estado otorgará los beneficios de la seguridad social, que tendrá carácter de integral e irrenunciable. En especial, la ley establecerá: el seguro social obligatorio, que estará a cargo de entidades nacionales o provinciales con autonomía financiera y económica, administradas por los interesados con participación del Estado, sin que pueda existir superposición; jubilaciones y pensiones móviles; la protección integral de la familia; la defensa del bien de familia, la compensación económica familiar y el acceso a una vivienda digna".

Concordantemente, se modificó el artículo 67, inciso $11^{(10)}$, encargándose al Congreso Nacional el dictado de un Código del Trabajo

(7) Toda la argumentación efectuada por el convencional Valenzuela para consagrar los derechos de los ancianos fue de mérito. Además de los fragmentos de su discurso que ya hemos trascripto, manifestó, como corolario de su exposición, lo siguiente: "La inclusión de los derechos de la ancianidad en la Constitución es un cambio, pero en un sentido limitado: cambiamos un olvido por un recuerdo. Estamos seguros de que las reglas consuetudinarias y legales de que se nutren estos derechos, y las que se aplicarán a ellos, coincidirán en sus resultados con nuestro ideal de justicia. Cuando se habla de un anciano, entre argentinos, el ánimo de todos promueve en el círculo familiar, en cualquier círculo, una atmósfera de comprensión profunda. Yo no creo que uno solo de los señores convencionales no haya creído, una vez en su vida, que un anciano debía ser asistido, debía vivir bajo techo, alimentarse, vestirse, cuidar su salud, compartir nuestro esparcimiento, trabajar en una actividad menuda, estar tranquilo y disfrutar del respeto y la consideración de sus semejantes. Este es el decálogo cuyo estado constitucional proponemos. Sostenemos que sus máximas estaban en nuestras conciencias y que lo estarán mientras haya un argentino sobre la tierra. Por eso aspiramos a que las generaciones que nos sucedan se enteren de que nosotros los hicimos trascender de nuestra intimidad para fijarlos en una ley vital".

(8) Mediante la proclama que la llamada Revolución Libertadora dictó el 27 de abril de 1956.

(9) Con las enmiendas efectuadas en 1866 y 1898 (que intencionalmente hemos omitido mencionar, debido a que nada aportaron a la temática que es objeto del presente estudio).

(10) Actual artículo 75, inciso 12. 


\section{La ancianidad en el Derecho Constitucional argentino Old age in Argentine Constitutional Law}

\begin{abstract}
y Seguridad Social(11). Si bien éste no se elaboró jamás y continuó la dispersión en tales materias, la norma constitucional contribuyó a deslindar las facultades al respecto entre Nación y Provincias.
\end{abstract}

La competencia provincial quedó desde entonces limitada, ya que por imperio de la Reforma de 1957, corresponde prioritariamente a la Nación legislar y reglamentar acerca de asuntos previsionales. Así las cosas, las provincias sólo pueden actuar en la franja no operativa del Estado federal, salvo que concedan beneficios mayores a los que brinda éste. Por otro lado, nada obsta que establezcan regímenes de seguridad social para los empleados públicos y los profesionales liberales ${ }^{(12)}$.

\subsubsection{Reforma de 1994}

La Reforma llevada a cabo en el año 1994 produjo destacables avances con relación a los ancianos, fundamentalmente mediante la adjudicación de jerarquía constitucional a diversos tratados internacionales, cuyas disposiciones deben entenderse complementarias de los demás derechos y garantías reconocidos en la parte dogmática de la Ley Fundamental (Lopresti 1998, 164; Pérez 1999, XXI-XXII; Sabsay y Onaindia 2000, 234).

El artículo 75, inciso 22, es el que, a través de una enumeración taxativa pero abierta ${ }^{(13)}$, incorpora las citadas convenciones -todas multilaterales-al orden constitucional argentino, refiriéndose varias de ellas a cuestiones vinculadas con la protección de las personas mayores. Verbigracia, así lo hacen la Declaración Universal de Derechos Humanos (arts. 1, 2.1, 7, 22 y 25.1), el Pacto Internacional de Derechos Civiles y Políticos (arts. 2.1 y 26), el Pacto Internacional de Derechos Económicos, Sociales y Culturales (arts. 9, 11.1 y 12.1), la Declaración Americana de los Derechos y Deberes del Hombre (arts. II, XVI y XXX) y la Convención Americana sobre Derechos Humanos (arts. 1.1 y 24) (Gonem 1996, 86; Tomasello 2002, 932).

Igualmente, otros dos incisos del artículo 75 de la Constitución reformada, merecen ser mencionados. El 19, que prevé que corresponde al Congreso "proveer lo conducente al desarrollo humano", asegurando una educación que promueva "la igualdad de oportunidades y posibilidades sin discriminación alguna"(14). Y el 23, que establece como deber del Parlamento Nacional llevar adelante "medidas de acción positiva que garanticen la igualdad real de oportunidades y de trato, y el pleno goce y ejercicio de los derechos reconocidos por esta Constitución y por los tratados internacionales

(11) Un antecedente de esta disposición lo constituyó el artículo 68, inciso 11, de la Constitución de 1949, que atribuía al Parlamento la responsabilidad de sancionar un Código de Derecho Social.

(12) En efecto, ello es lo que expresamente consagra el artículo 125, in fine, de la Constitución vigente. Al respecto, la Corte Suprema de Justicia de la Nación ha afirmado que "las provincias pueden crear y reglamentar regímenes de previsión y seguridad social dentro del ámbito de los agentes de la administración pública, de los magistrados y funcionarios de sus tribunales, de los integrantes de las legislaturas y, también, en virtud del ejercicio del poder de policía retenido, sobre la práctica de las profesiones liberales" (C.S.J.N., in re "Cena, Juan M. c/ Provincia de Santa Fe", 18/11/1999).

(13) Aunque a primera vista pueda parecer contradictorio que exista una enumeración "taxativa pero abierta", ello efectivamente sucede. Es taxativa en el sentido de que sólo los tratados expresamente mencionados en la Carta Magna gozan de jerarquía constitucional, y es abierta porque pueden pasar a integrar la nómina otros instrumentos jurídicos internacionales, siempre que el Congreso los apruebe con el voto de las dos terceras partes de la totalidad de los miembros de cada Cámara (Baeza 2000, 208-209).

(14) El inciso 19 del artículo 75 constituye la denominada "nueva cláusula del progreso" (la tradicional es la que actualmente se mantiene en el inciso 18), entendido éste como "el aprovechamiento de todas las potencialidades de los recursos naturales, humanos, de capital y tecnológicos, pero además incorporando el concepto de equidad, justicia y solidaridad", como lo expresó -con cita de Julio Olivera- el convencional Rodríguez al fundamentar la incorporación de esta cláusula (Baeza 2000, 198). 


\section{Mariano Horacio Novelli}

vigentes sobre derechos humanos, en particular respecto de (...) los ancianos"(15).

Tal es el panorama general actual acerca de los derechos de la ancianidad en la Carta Magna argentina. Como se ha visto, tras la supresión de la Constitución de 1949, se produjo un retroceso en la materia. Pero la última reforma ha logrado nuevos avances, que también cabe reconocer.

\subsection{Las constituciones provinciales}

\subsubsection{Cuestiones generales}

Llegado este punto, es necesario formular dos aclaraciones, con el objeto de fundamentar el método que hemos decidido seguir.

Primeramente, y antes de estudiar las disposiciones específicas que las constituciones provinciales destinan a la ancianidad, efectuaremos una breve síntesis de la evolución que ha ido sufriendo el Derecho Constitucional en cada jurisdicción. Ello, no solamente para otorgar un marco general de referencia, sino también para obtener una ubicación precisa del momento histórico en que los derechos de los ancianos fueron consagrados en los diversos ordenamientos, ya que no resulta casual que en su totalidad lo hayan sido durante el último ciclo, esto es, el del constitucionalismo social.

En segundo lugar, ya al analizar los derechos de los mayores en cada carta magna, consideraremos tanto aquellas normas que van dirigidas directamente a los ancianos de modo integral (verbigracia, las que establecen derechos particulares para éstos) como otras que únicamente los abarcan desde un determinado aspecto, por ejemplo, el previsional(16). Estimamos que ambas apuntan a mejorar las condiciones de vida de las personas de edad, y es ello en definitiva lo que reviste interés a los fines del presente estudio.

\subsubsection{Ciclos del Derecho Constitucional provincial argentino \\ 2.2.2.1. Primer ciclo: constitucionalismo inicial El constitucionalismo inicial llega hasta el dictado de la Constitución Nacional en 1853. Si bien se trata de un constitucionalismo rudimentario, poco desarrollado, permite advertir una actitud sincera del legislador, que pocas veces se repetirá luego, al menos con tal magnitud.}

Como primera manifestación se detecta, para algunos, el Reglamento Provisional dictado por el general Manuel Belgrano para Misiones (12 de diciembre de 1810), con reglas que incluso son de avanzada en materia de Derecho Social. Sin embargo, lo más frecuente es asignar al Estatuto Provisorio de 1819, de la Provincia de Santa $\mathrm{Fe}$, la condición de primera Constitución local en la Argentina.

Durante este período se sancionaron dieciséis constituciones $^{(17)}$.

\subsubsection{Segundo ciclo: constitucionalismo alberdiano}

En el tramo 1853-1860, las provincias van dictando sus constituciones conforme a la nacional. El Congreso federal tenía entonces la facultad de revisarlas ${ }^{(18)}$, y basándose en ello corrigió varios de esos textos.

(15) Este precepto legal únicamente estipula la necesidad de respetar el derecho a la igualdad en sentido material, debiendo por ende interpretarse e integrarse a la luz del artículo 16 -como vimos supra, originario de la Constitución de 1853-, que consagra el principio de igualdad formal (Dabove 2001-2002, 77).

(16) En el caso de la Seguridad Social, ya hemos apuntado que la actuación de las provincias es, en algunos aspectos, subsidiaria con relación a la de la Nación. Igualmente, no se trata de una tarea menor, sino complementaria, y es por tal motivo que resulta de interés detallar la normativa provincial respectiva.

(17) Catamarca (1823 -Reglamento Constitucional-), Córdoba (1821 -Reglamento Provisorio-, 1847 -Código Constitucional Provisorio-), Corrientes (1821 -Reglamento Provisorio Constitucional-, 1824), Entre Ríos (1822 -Estatuto Provisorio Constitucional-), Jujuy (1839 -Estatuto Provincial-, 1851 -Estatuto Provisorio para la Dirección y Administración-), Salta (1821 -Estatuto-), San Juan (1825 -Carta de Mayo-), San Luis (1832 -Reglamento Provisorio para el Régimen y Gobierno-), Santa Fe (1819 -Estatuto Provisorio-, 1841), Santiago del Estero (1830 -Reglamento para la Organización Política-), Tucumán (1820, 1852 -Estatuto Provincial-).

(18) Artículo $5^{\circ}$ de la Constitución Nacional de 1853. 


\section{La ancianidad en el Derecho Constitucional argentino Old age in Argentine Constitutional Law}

La mayoría de estas constituciones sigue el modelo elaborado por Alberdi para la Constitución de la Provincia de Mendoza. Como característica se constata la presencia de un poder municipal, junto a los tres poderes clásicos.

Durante esta etapa se aprobaron catorce constituciones ${ }^{(19)}$.

\subsubsection{Tercer ciclo: constitucionalismo liberal posterior a la reunificación nacional}

A partir de 1860 , las provincias van dictando nuevas constituciones, de corte ideológico liberal, decayendo el poder municipal alberdiano, a la par que la sistematización y la técnica jurídicas van mejorando ${ }^{(20)}$.

\subsubsection{Cuarto ciclo: constitucionalismo social}

2.2.2.4.1. Constitucionalismo social de vanguardia

El constitucionalismo social de vanguardia se perfila en constituciones pioneras (Tucumán, 1907; Mendoza, 1916) y en otras de mayor desarrollo (Santa Fe, 1921; San Juan, 1927).

\subsection{Constitucionalismo justicialista}

El constitucionalismo justicialista fue desplegado como consecuencia de la Constitución Nacional de 1949, imitada y aceptada por todas las provincias.

Asimismo, comprende las constituciones de las nuevas provincias de Chaco, La Pampa y Misiones.

Todas fueron derogadas por el gobierno provisional en 1956, según la proclama que abolió también la Constitución Nacional|(21).

2.2.2.4.3. Constitucionalismo "de las nuevas provincias" El constitucionalismo "de las nuevas provincias" surge a partir de 1957, cuando Chaco, La Pampa y Misiones adoptan nuevos textos que se apartan ideológicamente del justicialismo -entonces proscripto-, lo mismo que otras nuevas provincias que van surgiendo (Río Negro, Chubut, Santa Cruz, Neuquén y Formosa).

El ritmo ideológico es propio de un Estado social de Derecho, con algunos mecanismos de reciente factura en el derecho comparado (por ejemplo, el Consejo de la Magistratura, en Chaco y Río Negro), afirmándose también el régimen autonómico de los municipios.

Algunas constituciones de las denominadas provincias históricas se suman a este flujo social (Santa Fe, en 1962; Catamarca, en 1965).

2.2.2.4.4. Constitucionalismo contemporáneo El constitucionalismo contemporáneo se dio desde 1983, cuando casi la totalidad de las provincias $^{(22)}$ enmendaron sus constituciones o dictaron otras nuevas, incurriendo muchas veces en el error de hacerlas demasiado extensas y declamatorias.

Por lo común, se acentúan en ellas las pautas del Estado social de Derecho, pero también se asimilan nuevos dispositivos como el ombudsman, procesos legisferantes abreviados, tutela de los intereses difusos, derechos de tercera generación, y con frecuencia se modernizan los sistemas de selección de jueces, mediante los concursos, escuelas judiciales y consejos de la magistratura.

(19) Buenos Aires (1854), Catamarca (1855), Córdoba (1855), Corrientes (1855), Entre Ríos (1860), Jujuy (1855), La Rioja (1855), Mendoza (1854), Salta (1855), San Juan (1856), San Luis (1855), Santa Fe (1856), Santiago del Estero (1856), Tucumán (1856).

(20) A esta época corresponden las constituciones de Buenos Aires (1873), Córdoba (1870), Corrientes (1889, 1913), Entre Ríos (1883), Jujuy (1876, 1910), Mendoza (1894), Salta (1875), San Juan (1876) y Tucumán (1884).

(21) Corresponden a este período las constituciones de Buenos Aires (1949), Catamarca (1949), Córdoba (1949), Corrientes (1949), Chaco (1951), Entre Ríos (1949), Jujuy (1949), La Pampa (1952), La Rioja (1949), Mendoza (1949), Misiones (1954), Salta (1949), San Juan (1949), San Luis (1949), Santa Fe (1949), Santiago del Estero (1949) y Tucumán (1949).

(22) Salvo Santa Fe. 
Mariano Horacio Novelli

2.2.3. Tratamiento de la ancianidad en las constituciones provinciales

2.2.3.1. Ciudad Autónoma de Buenos Aires ${ }^{(23)}$

La Constitución de la Ciudad de Buenos Aires ${ }^{(24)}$ aborda la temática de la ancianidad en un artículo específico, al que complementan algunas otras disposiciones aisladas y de menor amplitud.

El artículo 41, correspondiente al Capítulo Duodécimo, Personas mayores, del Título Segundo, Políticas especiales, del Libro Primero, afirma que:

"La Ciudad garantiza a las personas mayores la igualdad de oportunidades y trato y el pleno goce de sus derechos. Vela por su protección y por su integración económica y sociocultural, y promueve la potencialidad de sus habilidades y experiencias. Para ello desarrolla políticas sociales que atienden sus necesidades específicas y elevan su calidad de vida; las ampara frente a situaciones de desprotección y brinda adecuado apoyo al grupo familiar para su cuidado, protección, seguridad y subsistencia; promueve alternativas a la institucionalización".

Es un precepto de carácter integral (López 1997, 71), que se adecua con las "acciones positivas" que fomenta el artículo 75, inciso 23, de la Constitución Nacional reformada en 1994 (Quiroga 1996, 125). En ese marco jurídico se deben considerar la garantía y tutela impuestas a favor de la protección de los ancianos, de su integración económica y sociocultural, así como la promoción de sus aptitudes laborales o artesanales y de las experiencias de cada individuo.

La norma -que ratifica "los principios de no discriminación e igualdad real de oportunidades consagrados en el artículo 11 de la Constitución porteña" (Sabsay y Onaindia 1997, 104)fija la política estatal en la materia, propiciando el desarrollo de medidas sociales dirigidas a satisfacer las necesidades propias del sector y mejorar su calidad de vida, e impulsando la concreción de proyectos que resguarden a la persona mayor y a su grupo familiar a fin de que éste le brinde seguridad, lo cuide y le garantice la subsistencia. Todo un marco programático que, no obstante, no podrá ser desconocido por las autoridades a la hora de aplicar la legislación vigente, porque, en tal caso, lo programático se convierte en operativo y puede ser exigible en la instancia jurisdiccional (Quiroga 1996, 126) ${ }^{(25) .}$

La promoción de alternativas a la institucionalización de quienes se encuentran en la tercera edad, propicia la formación de asociaciones que los representen, con legitimación procesal suficiente, así como la incorporación de sus representantes en organismos consultivos o de control que deberán crearse a efectos de que la norma tenga plena vigencia y respeto en la realidad (Quiroga 1996, 126).

Empero, además del artículo 41, también existen otros tres en la Constitución porteña que atañen a los ancianos: el 21 , el 80 y el 104.

El artículo 21, inciso 6, impone a la Legislatura el deber de sancionar una ley básica de salud, que ha de tener como lineamiento reconocer a la tercera edad "el derecho a una asistencia particularizada". Es una expresión escueta pero bien intencionada, que muestra el interés del constituyente por el cuidado psíquico y físico de las personas que se hallan en este estadio vital.

(23) A los fines del presente trabajo, incluimos la Ciudad Autónoma de Buenos Aires entre las provincias, comprendiendo que su status jurídico es prácticamente el mismo. El único distingo de ésta respecto de aquéllas está dado por la circunstancia de que el Congreso Nacional puede limitar la autonomía de la ciudad con el objeto de garantizar los intereses del Estado federal, mientras ella sea el ámbito de funcionamiento de la capital.

(24) Sancionada el $1^{\circ}$ de octubre de 1996, en cumplimiento del artículo 129 de la Constitución Nacional reformada en 1994.

(25) Reafirmando este postulado, se ha señalado que "tanto las normas como los principios constitucionales tienen operatividad por sí mismos, no siendo indispensable que las declaraciones, derechos y garantías, que consagra la Constitución, deban ser reglamentadas" (Cassagne 1998, 1:127). 


\section{La ancianidad en el Derecho Constitucional argentino Old age in Argentine Constitutional Law}

Por su parte, el artículo 80, que consagra las atribuciones del Poder Legislativo de la Ciudad, establece, en su inciso $7^{(26)}$, que la Legislatura "promueve medidas de acción positiva que garanticen la igualdad real de oportunidades y de trato (...) sobre personas mayores".

Finalmente, el artículo 104, inciso 30, atinente al Poder Ejecutivo, estipula que el Jefe de Gobierno "organiza consejos consultivos que lo asesoran en materias tales como (...) personas mayores". Es una posibilidad interesante que la Constitución otorga al primer mandatario porteño, permitiéndole acceder a la opinión y los puntos de vista que tienen los ancianos sobre su propia problemática.

\subsubsection{Provincia de Buenos Aires}

La Constitución de la Provincia de Buenos Aires ${ }^{(27)}$, a pesar de ser relativamente reciente y de poseer un tinte solidarista importante, sólo cuenta con un artículo que -en un único inciso- aborda la ancianidad. Es el número 36, que dispone:

"La Provincia promoverá la eliminación de los obstáculos económicos, sociales o de cualquier otra naturaleza, que afecten o impidan el ejercicio de los derechos y garantías constitucionales.

A tal fin reconoce los siguientes derechos sociales:

(...)

6. De la tercera edad. Todas las personas de la tercera edad tienen derecho a la protección integral por parte de su familia. La Provincia promoverá políticas asistenciales y de revalorización de su rol activo".

La norma, sucinta, se halla en una más extensa serie de derechos de carácter social, que introduce el mismo artículo(28). Respecto de los ancianos establece un solo derecho -a la protección integral-, cuyo cumplimiento pone en cabeza de su familia, a la par que el Estado provincial asume el deber de promover políticas de asistencia y jerarquización de su papel social.
Sin embargo, la circunstancia de que la disposición sea sencilla e incluso programática, no obsta -ni siquiera limita-la posibilidad para la persona mayor de reclamar la efectividad de sus derechos. Ello, porque el hecho de que la primera parte del artículo proteja a la tercera edad como un sector social previsto de ser contemplado en la eliminación "de los obstáculos económicos, sociales o de cualquier naturaleza, que afecten o impidan el ejercicio de los derechos y garantías constitucionales", tiene un marco normativo que el legislador no puede desconocer. $Y$ "frente a la omisión del legislador, y ante el estado de necesidad de un derecho fundamental, los jueces podrán hacer lugar a la tutela del amparo, porque para eso las normas constitucionales hablan de "acción u omisión' de cualquier autoridad pública" (Quiroga 1995, 88-89)(29).

\subsubsection{Provincia de Catamarca}

La Constitución de la Provincia de Catamarca( ${ }^{(30)}$ cuenta con una disposición que aborda los derechos de la ancianidad en su conjunto, y otra que se limita al aspecto previsional.

La primera de ellas es el artículo 65, que expresa:

"Sin perjuicio de los derechos sociales generales reconocidos por esta Constitución, dentro de sus competencias propias, la Provincia garantiza los siguientes derechos especiales:

$(\ldots)$

(26) Concordante con el artículo 41 (el cual, como hemos referido supra, sigue a su vez la pauta general sentada por el artículo 11).

(27) De conformidad con el texto que aprobó la Convención Constituyente Reformadora el 13 de septiembre de 1994.

(28) En la Constitución vigente hasta 1994 prevalecía el tratamiento de derechos individuales, que contaban con una amplia protección. La reforma extendió ésta a los derechos sociales (Mayón 1995, 26).

(29) En posición contraria, se ha afirmado que la norma "para su operatividad requerirá de legislación y disposiciones que posibiliten la efectiva protección de los derechos sociales enumerados" (Scotti 1995, 55).

(30) De acuerdo con su última reforma, que fue aprobada el 3 de septiembre de 1988 y tuvo por objeto "adecuarla a las necesidades actuales, y especialmente, (...) incorporar los derechos sociales y económicos no contemplados en ella”, según lo enuncia el preámbulo. 
Mariano Horacio Novelli

V - De la ancianidad:

$1^{\circ}$ - A las condiciones sociales, económicas y culturales que permitan su natural integración a la familia y la comunidad.

$2^{\circ}$ - Al haber previsional justo y móvil y a la inembargabilidad de parte sustancial del mismo.

$3^{\circ}$ - A la asistencia, alimentación, vivienda, vestido, salud física y moral, ocupación por la laborterapia productiva, esparcimiento y turismo, a la tranquilidad y respeto. La Provincia protege especialmente la ancianidad en casos de desamparo".

Igualmente, in fine, remite a una ley especial la tarea de asegurar la operatividad de los derechos reconocidos, de lo cual "debe entenderse que una o varias leyes especiales disciplinarán las normas complementarias" (Frías et al. 1989, 261).

Resulta clara la finalidad protectoria de la enunciación de derechos, que procura insertar al anciano en el ámbito social, mantenerlo a resguardo de afectaciones económicas y brindarle un marco general de contención afectiva y cuidado de su persona.

En cambio, el artículo 180, relativo al Régimen administrativo y rentístico de la provincia, se vincula con la senectud desde una óptica de alcance específico y delimitado. Dispone que la ley debe organizar y garantizar el régimen de previsión social, respetando determinadas pautas, a saber:

"1. - Jubilación ordinaria, con un haber igual al 82 \% móvil de las remuneraciones de los cargos desempeñados en actividad.

2. - Jubilaciones por incapacidad sobreviniente, por disfuncionalidad, por edad avanzada, retiro voluntario, retiros policiales y pensiones.
3. - Las prestaciones serán móviles y estrictamente proporcionales al tiempo trabajado y a los aportes realizados.

4. - Se asegura también la Jubilación para el Ama de Casa, promoviendo la inclusión de todas las mujeres que habiten el territorio Provincial y se desempeñen como tales"(31).

Se trata de principios importantes, indicadores de la voluntad del constituyente catamarqueño de coadyuvar a que, mediante dignos haberes jubilatorios, las personas mayores puedan disfrutar de una adecuada calidad de vida.

\subsubsection{Provincia del Chaco}

La Constitución de la Provincia del Chaco ${ }^{(32)}$ reseña los derechos de la ancianidad en uno de los puntos del artículo 35, Familia, correspondiente al capítulo Derechos sociales, el cual afirma:

"Esta Constitución asegura los siguientes derechos:

(...)

4. De la ancianidad. Protección integral de los ancianos y su inserción social y cultural, procurando el desarrollo de tareas de creación libre, de realización personal y de servicio a la comunidad".

El legislador ha evitado formular una enunciación exhaustiva, prefiriendo mencionar derechos lo suficientemente abarcativos como para facilitar a la persona mayor una eventual tutela jurisdiccional. Aun así, la disposición es de utilidad a los fines de contemplar la visión que de los ancianos revela la Constitución del Chaco, comprendiéndolos dentro de

(31) Transcribimos exclusivamente los primeros cuatro incisos del artículo 180, en razón de ser los de interés para el presente estudio.

(32) Según el texto aprobado por la Convención Constituyente Reformadora el 27 de octubre de 1994. 


\section{La ancianidad en el Derecho Constitucional argentino Old age in Argentine Constitutional Law}

un complejo social y cultural que actúa como grupo de pertenencia.

En la faz económica, el citado ordenamiento proclama, en su artículo 29, que todo trabajador goza del derecho a jubilaciones y pensiones móviles. Es coincidente esta norma con la del tercer párrafo del artículo 14 bis de la Carta Magna argentina.

\subsubsection{Provincia del Chubut}

La Constitución de la Provincia del Chubut ${ }^{(33)}$ contempla la temática de la ancianidad en un precepto específico y en otros dos más generales (uno que consagra el principio de no discriminación y el otro que refiere a las políticas de seguridad social).

El artículo 29, "De la ancianidad", ubicado en el capítulo relativo a los Derechos Sociales, pauta que:

"La familia prioritariamente, la sociedad y el Estado procuran la protección del anciano evitando su marginación social y cultural, promoviendo el desarrollo de tareas creativas y de servicio a la sociedad a los fines de su realización personal.

En caso de desamparo debe el Estado proveer a su protección sin perjuicio de la obligación de subrogarse en el ejercicio de las acciones para demandar los aportes correspondientes a los familiares obligados".

La disposición establece un triple orden de responsabilidad con respecto al cuidado de las personas mayores, pero haciendo hincapié en que el deber primordial está a cargo de la familia. Entre los tres agentes, cuyo actuar ha de ser coordinado y simultáneo (pues la mayor cercanía de los parientes, no exime en modo alguno a la sociedad ni al Estado), han de formar un círculo de contención que impida que el anciano quede sin amparo, o carezca de posibilidades de proyección.

La segunda parte de la norma muestra la decisión del Estado de no permanecer ajeno ante la pasividad de los familiares remisos y solventes de la persona mayor, a los cuales debe intimar a fin de que cumplan con las prestaciones pertinentes ${ }^{(34)}$.

La cláusula en análisis vino a ser reglamentada mediante la Ley I No 193 de Promoción y Protección Integral de la Tercera Edad, cuyo artículo $1^{\circ}$ fomenta "la protección integral, la promoción y la participación e integración de los miembros de la Tercera Edad en la sociedad chubutense, como así también la plena vigencia de los derechos reconocidos por el artículo 29 de la Constitución Provincial". En tal sentido, el artículo $3^{\circ}$ impone que debe asegurarse a las personas mayores la realización de los derechos referentes a: a) La atención de la salud física y psíquica; b) La permanencia en la familia; c) La adecuada nutrición; d) La vestimenta digna; e) La vivienda adecuada; f) El esparcimiento; g) La participación e integración en la sociedad; h) El acceso a la educación formal y no formal; i) El acceso al trabajo terapéutico; j) El reconocimiento a su labor; k) La previsión social; I) La no discriminación; m) La dignidad (Gerosa Lewis 2002, 125-126) ${ }^{(35)}$.

(33) Conforme a su última reforma, efectuada con fecha 11 de octubre de 1994.

(34) Decimos "debe intimar", puesto que la norma es clara en el sentido de que existe obligación de subrogarse por parte del Estado. En efecto, rige el principio de la subsidiariedad activa, hallándose el Estado compelido "a subrogarse en las acciones que los beneficiarios de estas disposiciones poseen en contra de los obligados directos para repetir lo que hubiere debido disponer en su favor" (Heredia 1995, 140-141). Postulados similares traen, como lo apreciaremos infra, las Leyes Supremas de Río Negro y Tierra del Fuego, todas con antecedente, como vimos supra, en el primer derecho de la ancianidad ("derecho a la asistencia") enunciado en la Constitución Nacional de 1949.

(35) Además, la Ley I N 193 obliga a que "se adopten acciones preventivas (como por ejemplo crear ámbitos de participación para la investigación de la Tercera Edad; promover la interrelación de los diferentes organismos que se ocupan de la Tercera Edad, etc.) y ejecutivas (por ejemplo implementar planes de protección para garantizar la adecuada nutrición de los mayores, crear redes de contención, velar por el adecuado funcionamiento de las instituciones de atención para mayores, etc.) para lograr los objetivos previstos" (Gerosa 2002, 125-126). 


\section{Mariano Horacio Novelli}

Retornando al estudio de la Carta Magna chubutense, debemos poner de resalto que el artículo 7 ("No discriminación"), correspondiente a la sección de las declaraciones, enuncia explícitamente que la edad no es un elemento que pueda dar lugar a discriminación. Frente a las reglas de otras constituciones, circunscriptas a pautar una mera igualdad formal, resulta importante esta toma de posición del constituyente, que exige al Estado la remoción de todo obstáculo al pleno goce de derechos ${ }^{(36)}$.

El precepto en cuestión, que ha de ser llevado a la práctica con verdadera conciencia de su significado, expresa que "las diferencias de sexo, edad o capacidad no constituyen factores discriminatorios. El Estado garantiza el respeto a las características emergentes de dichas diferencias y establece condiciones acordes con las mismas tendientes a la realización personal de todos sus habitantes".

Finalmente, en el capítulo atinente al "Régimen social" dentro del título sobre "Políticas del Estado", se halla el artículo 74, que garantiza el acceso al sistema previsional, sosteniendo que "Ia Provincia establece para todos sus habitantes regímenes de previsión y seguridad social que comprenden las consecuencias económicas y sociales de la (...) vejez".

\subsubsection{Provincia de Córdoba}

La Constitución de la Provincia de Córdoba ${ }^{(37)}$, de un hondo matiz social, trata aspectos relacionados con las personas de edad avanzada en tres artículos, de los cuales uno abarca sus derechos y los otros dos refieren a la faz previsional y a la responsabilidad de los Estados municipales en materia de vejez.

El artículo 28, que estipula los derechos de la ancianidad, señala que "el Estado Provincial, la familia y la sociedad procuran la protección de los ancianos y su integración social y cultural, tendiendo a que desarrollen tareas de creación libre, de realización personal y de servicio a la sociedad". Nuevamente, podría creerse, a partir de una interpretación literal, que nos encontramos frente a una disposición programática. Empero, es menester llevar adelante una interpretación teniendo en mira el elemento sistemático (Goldschmidt 1987, 258-259), para así comprender cabalmente la practicidad que entraña este precepto en el sistema de Derecho cordobés. Según el artículo 22 de la propia Constitución, los derechos y garantías establecidos en ella "son de aplicación operativa, salvo cuando sea imprescindible reglamentación legal". Entonces, cabe entender que lo prescrito por el artículo 28 es automáticamente exigible por todo anciano que vea afectado un bien jurídico tutelado por dicha norma.

El sistema de seguridad social es abordado por el artículo 57 que, en la parte pertinente, afirma:

"El Estado Provincial, en el ámbito de su competencia, otorga a los trabajadores los beneficios de la previsión social y asegura jubilaciones y pensiones móviles, irreductibles y proporcionales a la remuneración del trabajador en actividad.

El régimen previsional debe ser uniforme y equitativo y debe procurar la coordinación con otros sistemas previsionales".

Por otro lado, interesa destacar que la ancianidad y la previsión social están expresamente indicadas, de acuerdo al artículo 186 , inciso 7 , como parte de la competencia material de las municipalidades y comunas de la Provincia, en lo que constituye una de las dos únicas disposiciones de este tipo en el Derecho Constitucional provincial argentino ${ }^{(38)}$.

(36) La función del Estado es, precisamente, "buscar que esa 'igualdad formal' expresada en los textos constitucionales se transforme en una 'igualdad real', removiendo para ello los obstáculos de toda índole que le impiden a los individuos el pleno goce y ejercicio de sus derechos en un mismo pie de igualdad como así también su correcto desarrollo como personas" (Gerosa 2002, 49).

(37) Con las enmiendas efectuadas mediante la reforma concluida el 14 de septiembre de 2001.

(38) La otra está contenida en la Constitución de la Provincia de Santa Cruz, como lo señalaremos infra, en el curso del presente trabajo. 


\section{La ancianidad en el Derecho Constitucional argentino Old age in Argentine Constitutional Law}

\subsubsection{Provincia de Corrientes}

La Constitución de la Provincia de Corrientes ${ }^{(39)}$ consagra en su artículo 43 los "Derechos de la Ancianidad", del siguiente modo:

"Ninguna persona debe ser discriminada por causa de su edad. El Estado garantiza a las adultos mayores la igualdad real de oportunidades, trato y pleno goce de los derechos reconocidos en esta Constitución, en la Constitución Nacional, en los Tratados y en las leyes.

El Estado, mediante políticas sociales, vela por su protección e integración socio-económica y cultural, tendiente a cubrir sus necesidades específicas y a elevar su calidad de vida, y provee especialmente a la protección de los ancianos que se hallen en riesgo, abandonados y desamparados, dictando políticas de inclusión de forma directa o a través de terceros".

Se trata de un precepto abarcativo y palmariamente protectivo de los ancianos, a quienes garantiza igualdad real de oportunidades y trato -enfatizando la no discriminación-, así como el pleno goce de sus derechos. Además, resalta el deber del Estado con relación a la integración social, económica y cultural de las personas mayores, que debe lograrse mediante el desarrollo de políticas de inclusión.

\subsubsection{Provincia de Entre Ríos}

La Constitución de la Provincia de Entre $\operatorname{Ríos}^{(40)}$ se refiere a los ancianos en el tercer párrafo de su artículo 18, en los siguientes términos:

"Con la participación de la familia, el Estado reconoce a los adultos mayores el pleno ejercicio de sus derechos, brindándoles asistencia, seguridad y previsión social. Promueve la conciencia de respeto y solidaridad entre las generaciones. Y los protege contra toda violencia".
De modo que la ley suprema entrerriana cuenta, como es habitual en los textos constitucionales de años recientes, con una disposición que aborda concretamente la problemática de las personas de edad avanzada. Vale enfatizar el modo explícito en que rechaza la violencia que, huelga decirlo, constituye un concepto que debe interpretarse en su más amplia acepción.

\subsubsection{Provincia de Formosa}

La Constitución de la Provincia de Formosa ${ }^{(41)}$ incluye un completo artículo que procura comprender la compleja problemática de la vejez, y otros dos que muy brevemente delinean la política de seguridad social.

El artículo 71, perteneciente al Capítulo Cuarto ("Régimen social") y de profusa redacción ${ }^{(42)}$, dice:

"El Estado propiciará para las personas de la tercera edad una protección integral que las revalorice como activos protagonistas de esta sociedad.

En caso de desamparo corresponde al Estado proveer dicha protección, ya sea en forma directa o por intermedio de institutos y fundaciones creados o por crearse, con estos fines: atención de carácter familiar; establecimientos especiales organizados con fines preventivos; hogares o centros de día; asistencia integral domiciliaria; acceso a la vivienda a través del crédito de ampliación, de adjudicación en propiedad o en comodato de por vida, asignando

(39) Aprobada el 8 de junio de 2007.

(40) Aprobada el 3 de octubre de 2008.

(41) Sancionada el 7 de julio de 2003.

(42) No creemos que sea desacertada la decisión de los constituyentes de ser precisos y minuciosos en cuanto a los objetivos que ha de tener la política estatal en materia de ancianidad. Ubicado en una postura estrictamente dogmática, no faltará quien señale que tan detallada enumeración es impropia de un texto constitucional, y que bien podía haber quedado para las leyes ordinarias. No obstante, desde una visión empírica, nos parece que se ha buscado dejar sentadas bases firmes, que los miembros de los tres poderes estatales deban respetar y hacer respetar. Si bien es una solución cuestionable, estimamos que se trata de un atinado criterio. 
Mariano Horacio Novelli

un porcentaje de las viviendas que se construyan con fondos nacionales, provinciales y municipales; promover su reinserción laboral con fines de laborterapia y aprovechamiento de su experiencia y capacitación, la cual será reglamentada por una ley para el justo goce de dicho derecho"(43).

Los otros dos artículos ligados a las personas mayores, que abordan a éstas exclusivamente desde el aspecto previsional, son el 76 y el 82 . El primero de ellos garantiza "un régimen de seguridad social que comprenderá a toda la población, durante el transcurso de la existencia humana, contemplando las contingencias económico-sociales de la (...) vejez"; el segundo, en su inciso 12, señala que la ley asegurará jubilación y pensiones móviles.

\subsubsection{Provincia de Jujuy}

La Constitución de la Provincia de Jujuy ${ }^{(44)}$ prevé la tutela de los ancianos en su artículo 49, el cual expresa:

"Las personas de edad avanzada tienen derecho a la seguridad económica y social, al goce de la cultura, del tiempo libre, a una vivienda digna y a condiciones de convivencia que tiendan a proporcionarles oportunidades de realización plena a través de una participación activa en la vida de la comunidad".

Es una disposición concisa pero que permite apreciar el interés que, desde la Carta Magna provincial, se proyecta hacia la temática de la vejez. En adición, las breves líneas que conforman el precepto enuncian -si bien de un modo genérico- los derechos fundamentales de los ancianos, de cuya efectividad son responsables tanto el aparato administrativo y jurisdiccional como la comunidad toda. En definitiva, son derechos sociales que "recobran un acento ético" (Frías y otros 1989, 244).

Por su parte, el artículo 59, inciso 2, apartado 1), prescribe que el régimen de previsión social se organizará teniendo como base el "beneficio jubilatorio móvil".

\subsubsection{Provincia de La Pampa} La Constitución de la Provincia de La Pampa(45) no hace referencia a las personas mayores en ninguna parte de su articulado; llamativamente, tampoco cuenta con disposición alguna sobre asuntos de seguridad social.

Sin embargo, su artículo 31 afirma:

"La enumeración y reconocimiento de derechos que contiene esta Constitución expresamente o implícitamente por contenerlos la Nacional, no importa denegación de los demás que derivan de la condición natural del hombre y del sistema republicano de gobierno".

Una vez más, los derechos de los ancianos quedan a salvo por intermedio de una cláusula de "derechos no enumerados", con los alcances que hemos explicitado supra.

\subsubsection{Provincia de La Rioja}

La Constitución de la Provincia de La Rioja ${ }^{(46)}$ posee, en su Capítulo II ("Derechos y Garantías"), un artículo de "Protección a la Ancianidad” (Frías y otros 1989, 240). Se trata del número 38 , que sostiene:

"Todo anciano tiene derecho a la protección integral por cuenta y cargo de su familia. En caso de desamparo, corresponde al Estado proveer a dicha protección, ya sea en forma directa o por intermedio de los institutos o fundaciones creados para ese fin".

La norma dispone que la responsabilidad prioritaria de cuidado de las personas mayores corresponde a su familia. El Estado asume un

(43) Como veremos infra, el artículo ha sido tomado casi textualmente de la Constitución de la Provincia de San Luis, habiéndosele efectuado unas pocas modificaciones de forma.

(44) Aprobada el 22 de octubre de 1986.

(45) Con las reformas aprobadas el 6 de octubre de 1994.

(46) Según el texto sancionado por la Asamblea Constituyente el 14 de mayo de 2008. 


\section{La ancianidad en el Derecho Constitucional argentino Old age in Argentine Constitutional Law}

rol supletorio, en caso de falencias en el ejercicio de tal tutela, y nada se menciona acerca de políticas abarcativas de la problemática de los ancianos cuyo entorno social los contiene, los cuales también merecen atención desde el Derecho Público (por ejemplo, en los aspectos laborales, sanitarios y de esparcimiento, entre otros). Creemos que hubiera sido de utilidad la inclusión de alguna referencia al respecto.

Desde la específica perspectiva de la seguridad social, el artículo 47 señala:

"El Régimen Jubilatorio Provincial será único para todas las personas y asegurará la equidad y la inexistencia de privilegios que importen desigualdades que no respondan a causas objetivas y razonables.

El haber deberá ser móvil, irreductible y proporcional a la remuneración del mismo cargo en actividad".

\subsubsection{Provincia de Mendoza}

La Constitución de la Provincia de Mendoza(47) no contiene disposiciones que se dirijan a la vida de los ancianos. Se trata de un ordenamiento muy antiguo ${ }^{(48)}$, que nunca ha sido reformado integralmente ${ }^{(49)}$ ni ha receptado los principios del constitucionalismo social( ${ }^{(50)}$. Allí debe buscarse la explicación de tal carencia.

Empero, viene a solucionar la cuestión el artículo 47 -propio de la ideología liberal- que, en este punto, mediante una interpretación evolutiva, contribuye a captar elementos normativos de suma importancia. Enuncia que "la enumeración y reconocimiento de derechos que contiene esta Constitución, no importa denegación de los demás que se derivan de la forma republicana de gobierno y de la condición natural del hombre". Como cláusula de "derechos no enumerados" con la significación que le hemos adjudicado, el artículo comprende los relativos a las personas mayores.

\subsubsection{Provincia de Misiones}

La Constitución de la Provincia de Misiones ${ }^{(51)}$, de profunda raigambre social, legisla sobre ancianidad en el Capítulo Segundo ("Familia. Protección a la ancianidad y minoridad") del Título Tercero ("Derechos sociales"), correspondiente a la Sección Primera de su Primera Parte.

El artículo 37, primero de los dos que conforman el capítulo, prescribe en su inciso 2 (García 1984, 29; Biazzi 1982, 108) que la ley asegurará "el amparo a la maternidad, infancia, minoridad, a la incapacidad y a la ancianidad de quienes carecen de familia"; mientras que el $38^{(52)}$ dispone que "toda mujer que esté por dar a luz o haya dado a luz, todo anciano, todo incapacitado y todo menor de edad que se encuentre en estado de desamparo, serán protegidos por el Estado. A tal efecto la ley creará los organismos que asumirán esas tareas".

Ambos preceptos apuntan a generar un marco protectivo hacia grupos minoritarios, entre los cuales se contempla al compuesto por las personas de edad avanzada. Se halla implícita la responsabilidad principal de la familia en cuanto al cuidado de éstas, pues el Estado actúa sólo en caso de desamparo y no promueve -al menos desde la letra del

(47) Cuya última enmienda se introdujo por ley 5557, siendo aprobada en las elecciones generales del 8 de septiembre de 1991.

(48) Data del 11 de febrero de 1916.

(49) Sólo se cambiaron una veintena de artículos mediante la reforma del 1 de diciembre de 1965. El resto de las modificaciones han sido efectuadas a través de leyes ordinarias, lo cual sólo permite hacerlo respecto de un artículo por vez.

(50) Existe consenso en que "su temática central se inscribe dentro del Constitucionalismo clásico" (Ortiz, Borgarello y Aguirre 1994, 43).

(51) Cuya última modificación fue efectuada por la Cámara de Representantes el 15 de diciembre de 1988.

(52) Producto de una técnica legislativa objetable, pues su idea es prácticamente idéntica a la del 37 , por lo cual debieron haber conformado ambos postulados una única disposición. 
Mariano Horacio Novelli

texto constitucional- políticas o acciones positivas respecto de quienes no se hallan en tal situación.

\subsubsection{Provincia del Neuquén}

La Constitución de la Provincia del Neuquén ${ }^{(53)}$ expresa en su artículo 49, ubicado dentro del Capítulo II ("Derechos Sociales") del Título II de su Primera Parte:

"El Estado garantiza a las personas adultas mayores la igualdad de oportunidades y trato y el pleno goce de sus derechos.

El Estado y los demás sujetos obligados legalmente proveen a la protección de las personas adultas mayores y a su integración económica y sociocultural.

En caso de riesgo o desamparo corresponde al Estado proveer dicha protección, sin perjuicio de la obligación de subrogarse en el ejercicio de las acciones para demandar a quienes estuvieran obligados legalmente a asistirlos".

Corresponde poner de resalto dos cuestiones significativas de la redacción de esta cláusula. Por un lado, el hecho de que se refiera específica y exclusivamente a los adultos mayores, garantizando el goce pleno de sus derechos; y por otro, que ponga en pie de igualdad al Estado con los particulares a los fines de la protección y la integración de los ancianos, reforzando incluso la responsabilidad estatal en caso de situación de riesgo o desamparo.

A esta disposición de carácter amplio, se adiciona el derecho a un seguro social para caso de vejez, consagrado en los artículos 25 y 38 de la ley fundamental neuquina.

\subsubsection{Provincia de Río Negro}

La Constitución de la Provincia de Río Negro(54) incluye dos artículos vinculados con los ancianos, uno desde una óptica totalizadora de su dimensión vital y el otro circunscripto a aspectos de seguridad social.
El primero de ellos es el artículo 35, intitulado "Derechos de la tercera edad", que dice:

"Las personas de la tercera edad, por su experiencia y sabiduría continúan aportando al progreso de la comunidad. Se les garantiza el derecho a trabajar y a gozar del esparcimiento, tranquilidad y respeto de sus semejantes. Tienen derecho a su protección integral por cuenta y cargo de su familia. En caso de desamparo, corresponde al Estado proveer dicha protección, sin perjuicio de la obligación de subrogarse en el ejercicio de las acciones para demandar de los familiares obligados los aportes correspondientes".

Es una norma técnicamente correcta y, a diferencia de las de otras leyes supremas, no deja de lado derechos que hacen a que el anciano se sienta socialmente incluido, como los atinentes a la actividad laboral y a la recreación. Por otra parte, vale mencionar que, en materia de derechos de la persona-como son los que estamos tratando-, la Constitución se ha inclinado por la operatividad perentoria, "sin que su ejercicio pueda ser menoscabado por ausencia o insuficiencia de reglamentación", según lo indica su artículo 14 (Frías y otros 1989, 256).

En cuanto a la previsión social, el artículo 40, inciso 9, garantiza el derecho "a la obtención de una jubilación justa, no menor del ochenta y dos por ciento del ingreso total del sueldo del trabajador activo, sujeto a aporte"(55).

\subsubsection{Provincia de Salta}

La Constitución de la Provincia de Salta ${ }^{(56)}$ regula los derechos de la ancianidad en un

(53) Conforme al texto ordenado aprobado por la Convención Constituyente el día 17 de febrero de 2006.

(54) Sancionada el 3 de junio de 1988.

(55) Ya la antigua Constitución rionegrina de 1957 había sentado un antecedente importante en la materia, pues promovía un régimen de seguridad social integral y concedía al anciano el derecho inmediato de solicitar el auxilio que su vejez necesitara (Epifanio 1982, 25).

(56) Cuya última modificación fue efectuada el 30 de agosto de 2003. 


\section{La ancianidad en el Derecho Constitucional argentino Old age in Argentine Constitutional Law}

precepto de mérito, que asigna a la senectud como estadio vital su auténtica jerarquía.

Textualmente, el artículo 35 expresa:

"Se reconoce a la ancianidad el derecho a una existencia digna, considerándola como una etapa fecunda de la vida, susceptible de una integración activa sin marginación, y es deber del Estado proteger, asistir y asegurar sus derechos.

La Provincia procura a los habitantes de la tercera edad:

1. La asistencia.

2. La vivienda.

3. La alimentación.

4. El vestido.

5. La salud física.

6. La salud moral.

7. El esparcimiento.

8. El trabajo acorde con sus condiciones físicas.

9. La tranquilidad.

10. El respeto"(57).

Para más, todos estos derechos gozan de "plena operatividad" sin necesidad de reglamentación alguna, con arreglo al artículo 16, in fine, de la propia ley fundamental (Frías y otros. 1989, 236).

A la seguridad social se refiere, por su parte, el artículo 40. Pauta éste un régimen jubilatorio único para todas las personas, que asegure "la equidad y la inexistencia de privilegios que importen desigualdades que no respondan a causas objetivas y razonables". Paralelamente, se prescribe que "el haber previsional debe ser móvil y guardar estrecha relación con la remuneración del mismo cargo en actividad".

\subsubsection{Provincia de San Juan}

La Constitución de la Provincia de San Juan ${ }^{(58)}$ contiene una primera alusión al tema que nos ocupa en un artículo cuyo encabezado es sumamente gráfico: "Respeto a la persona". Es el número 19, que de modo terminante sostiene que "toda humillación a la persona por motivos de (...) edad, (...) es castigada severamente". Surge palmaria de esta disposición la intención del constituyente de dejar a resguardo a los seres humanos que, verbigracia por su avanzada edad, puedan ser objeto de discriminación.

Ubicado en el Capítulo IV ("Derechos, libertades y garantías sociales") de la Sección Primera (Ramella 1986, 848), el artículo 52 ("Protección de la familia") determina un factor importante relacionado con los ancianos, pues pone bajo la responsabilidad del Estado la organización de sistemas de protección para los problemas económicos y sociales que éstos padezcan.

Pero es el artículo 57 el que trata específicamente de la "Protección de la ancianidad", en los siguientes términos:

"El Estado y los habitantes deben propugnar a la protección de los ancianos y a su integración social y cultural evitando su marginación, con la finalidad de que éstos puedan llevar a cabo tareas de creación libre, de realización personal y de servicio para la sociedad".

Finalmente, el artículo 62 , párrafo $3^{\circ}$, apartado 6 , fija como competencia del Estado provincial, a través una legislación adecuada y de la implementación de planes y programas de política económica y social, garantizar "el derecho a la obtención de una jubilación digna y móvil con un haber que permita mantener el nivel de vida precedente".

\subsubsection{Provincia de San Luis} La Constitución de la Provincia de San Luis( ${ }^{(59)}$ se ocupa de la temática de la ancianidad

(57) Como puede advertirse, la Constitución salteña recoge los diez "derechos de la ancianidad" que establecía la derogada Constitución Nacional de 1949.

(58) Cuya última enmienda se tuvo por incorporada el 19 de mayo de 2011.

(59) Según el texto ratificado por la Convención Reformadora el 26 de marzo de 1987. 
Mariano Horacio Novelli

desde una faz integral, que atiende a los derechos, y desde otra más delimitada, que aborda el régimen jubilatorio. No innova demasiado en la materia, y continúa básicamente los lineamientos brindados por otras leyes superiores de provincia.

El artículo 51, inserto en el Capítulo I ("Declaraciones, Derechos y Garantías"), enuncia los "derechos de la tercera edad":

"El Estado asegura a los hombres de la tercera edad una protección integral que revalorice su rol como protagonista de esta sociedad. Propicia una legislación que contemple los múltiples aspectos que se plantean en el ámbito familiar, estimulando planes y programas que tiendan a su asistencia plena, por cuenta y cargo de sus familiares. En caso de desamparo, corresponde al Estado proveer a dicha protección, ya sea en forma directa o por intermedio de los institutos y fundaciones creadas o que se crearán con ese fin; a una atención de carácter familiar, a establecimientos especiales enfocados con mentalidad preventiva, a los hogares o centros de día, a la asistencia integral domiciliaria, al acceso a la vivienda a través del crédito de ampliación, de adjudicación en propiedad y/o comodato de por vida, a promover su reinserción laboral a los fines de laborterapia y aprovechamiento de su experiencia y capacitación".

Además de tal disposición, que abarca a la senectud desde la complejidad y le reconoce derechos, cabe exponer el modo en que la Carta Magna puntana organiza el régimen previsional, mediante sus artículos 56 y 58 , párrafo $4^{\circ}$, apartado 6 .

En lo esencial, se pauta un régimen jubilatorio único para todas las personas, cuyo objetivo es asegurar la equidad y eliminar privilegios que importen desigualdades que no respondan a causas objetivas y razonables. El haber previsional debe ser digno, móvil y guardar estrecha relación con la remuneración del mismo cargo en actividad, permitiendo de tal forma conservar el nivel de vida precedente. A estos efectos:

"el Estado garantiza que la jubilación ordinaria sea, como mínimo el ochenta y dos por ciento móvil de la remuneración correspondiente al cargo, oficio o función por el que haya optado el beneficiario, según la ley y que los demás beneficios sean discernidos en adecuada proporción con aquélla".

\subsubsection{Provincia de Santa Cruz}

La Constitución de la Provincia de Santa $\mathrm{Cruz}^{(60)}$ define como responsabilidad de los Estados municipales la atención de la ancianidad, por medio del artículo 150, que establece:

"En el ámbito territorial que la Legislatura le fije y conforme a criterios técnicos, el Municipio desarrollará su actividad y tendrá competencia en las siguientes materias, sin perjuicio de otras que las leyes le fijen: (...)

8) Atender lo inherente a (...) la ancianidad; (...) los servicios de previsión y asistencia social".

Profundiza en materia previsional, ya dentro de la esfera de incumbencia provincial, el artículo 55, que determina la instauración de "un régimen de seguridad social que comprenda toda la población durante el transcurso de la vida humana, contemplando las consecuencias económicas y sociales de la desocupación, nacimiento, maternidad, enfermedad, desamparo, invalidez y muerte".

Con relación a los derechos de los ancianos, éstos se hallan implícitos en virtud del artículo 8, que declara que "la enumeración y reconocimiento de derechos que contiene esta Constitución expresamente, o implícitamente por contenerlos la Nacional, no importan denegación de los demás que deriven de la condición natural del hombre, de la forma democrática de gobierno y de la justicia social". Es una cláusula de "derechos no enumerados" que, como lo hemos analizado con antelación, permite el ingreso a la ley suprema de los correspondientes a las personas mayores.

\subsubsection{Provincia de Santa Fe}

La Constitución de la Provincia de Santa Fe ${ }^{(61)}$

(60) Conforme al texto de la reforma aprobada el 27 de noviembre de 1998.

(61) Sancionada el 14 de abril de 1962. 


\section{La ancianidad en el Derecho Constitucional argentino Old age in Argentine Constitutional Law}

contempla la situación jurídica de los ancianos en el artículo 23 cuando señala la obligación estatal de brindar protección material y moral a la ancianidad, directamente o fomentando las instituciones privadas orientadas a tal fin.

Mas también se vinculan con las personas de edad avanzada otras dos disposiciones: el artículo 7, según el cual "el Estado reconoce a la persona humana su eminente dignidad y todos los órganos del poder público están obligados a respetarla y protegerla", y "el individuo desenvuelve libremente su personalidad, ya en forma aislada, ya en forma asociada, en el ejercicio de los derechos inviolables que le competen"; y el artículo 21, in fine, que instituye "un sistema de seguridad social, que tiene carácter integral e irrenunciable", propendiendo la ley al establecimiento del seguro social obligatorio y de jubilaciones y pensiones móviles, así como al de todo otro medio tendiente a igual finalidad(62).

\subsubsection{Provincia de Santiago del Estero}

La Constitución de la Provincia de Santiago del Estero( ${ }^{(63)}$ pauta los derechos de la ancianidad en su artículo 34, que dice:

"La familia prioritariamente, la sociedad y el Estado Provincial, atenderán a la asistencia y protección de los ancianos, propiciando que la legislación contemple: el acceso irrestricto a la salud, a la vivienda y su integración social y cultural, tendiendo a que desarrollen tareas de creación libre, de reinserción laboral, de realización personal y de servicios a la comunidad".

Es una norma que no presenta elementos novedosos a pesar de ser reciente, sino que más bien acoge algunos de los puntos más relevantes que mencionan las leyes supremas de otras provincias. De todos modos, logra captar la integridad de la vejez prácticamente en plenitud, puesto que alude al aspecto familiar, sanitario, habitacional, sociocultural, y de trabajo y proyección a nivel humano.

Debemos destacar, igualmente, que la precitada disposición se complementa con otra que sí se presenta como absolutamente inédita en el Derecho Público provincial. Se trata del artículo 36, que contempla los derechos del consumidor, en los siguientes términos:

"Los consumidores y usuarios tienen derecho en la relación de consumo, a la protección de su salud, en especial del cuidado de los alimentos en general y con estricto control de calidad de los destinados a planes de apoyo nutricional para la (...) ancianidad".

En efecto: la santiagueña es la única constitución argentina que protege al anciano en su rol de consumidor, exhibiéndose esto como un atinado avance en la protección que, desde el ámbito iuspublicista, puede y debe brindarse a los destinatarios finales de productos, en este caso alimenticios ${ }^{(64)}$.

\subsubsection{Provincia de Tierra del Fuego,} Antártida e Islas del Atlántico Sur

La Constitución de la Provincia de Tierra del Fuego, Antártida e Islas del Atlántico Sur ${ }^{(65)}$ aborda la temática de la ancianidad desde tres dimensiones: una socio-jurídica ${ }^{(66)}$, una previsional y una sanitaria.

Desde la primera de ellas, comprensiva de los derechos de la ancianidad, el artículo 21 expresa:

(62) El artículo 21 de la Constitución santafesina es concordante con el 14 bis de la Constitución Nacional (Galetti y Torressi 1983, 5).

(63) Según la reforma sancionada el 25 de noviembre de 2005.

(64) La cuestión se vincula directamente con la protección del ciudadano como consumidor, en su relación con el Estado (Luciani y Novelli 2001, 89-102).

(65) Sancionada el 17 de mayo de 1991.

(66) Utilizamos aquí el término "socio-jurídico" para indicar el modo en que la Carta Magna normativiza para protección de las personas de edad avanzada, por parte tanto del Estado mismo como de la sociedad. 
Mariano Horacio Novelli

"La familia prioritariamente, la sociedad y el Estado Provincial, atenderán la protección de los ancianos y su integración social y cultural, tendiendo a que desarrollen tareas de creación libre, de realización personal y de servicios a la comunidad.

En caso de desamparo corresponderá al Estado Provincial proveer dicha protección, sin perjuicio de la obligación de subrogarse en el ejercicio de las acciones para demandar los aportes correspondientes a los familiares obligados".

La disposición es casi idéntica a la del artículo 29 de la Constitución del Chubut, que la tuvo precisamente por fuente directa. Remitimos, ergo, a los comentarios que hemos realizado supra, al analizar dicha norma.

De la faz previsional se ocupa el artículo 51 de la ley suprema fueguina, el cual reza:

"El Estado Provincial, en el ámbito de su competencia, otorga a los trabajadores, reconociendo el derecho que les asiste, los beneficios de la previsión social y asegura jubilaciones y pensiones móviles, irreductibles y proporcionales a la remuneración del trabajador en actividad.

La ley establecerá un régimen previsional general, uniforme y equitativo, que contemple las diferentes situaciones o condiciones laborales y la coordinación con otros sistemas previsionales".

El mencionado precepto no debe interpretarse aisladamente, sino a la luz del artículo 16 , inciso 6 , que reconoce a todos los habitantes el derecho "a que se prevean y aseguren los medios necesarios para atender las exigencias de su vida y de la familia a su cargo en caso de (...) vejez, (...) que tiendan a un sistema de seguridad social integral".

Por último, debemos destacar la inclusión explícita de la vejez como una cuestión básica a considerar al organizar legalmente el sistema sanitario. A este respecto, el artículo 53 (“Salud"), señala:

"El Estado Provincial garantiza el derecho a la salud mediante acciones y prestaciones promoviendo la participación del individuo y de la comunidad. Establece, regula y fiscaliza el sistema de salud pública, integra todos los recursos y concreta la política sanitaria con el Gobierno Federal, los gobiernos provinciales, municipios e instituciones sociales, públicas y privadas.

La ley de salud pública provincial deberá como mínimo:

(...)

3. - Dar prioridad a la (...) tercera edad".

\subsubsection{Provincia de Tucumán}

La Constitución de la Provincia de Tucumán ${ }^{(67)}$ trata los derechos de los ancianos en su artículo 40, que señala:

"Dentro de la esfera de sus atribuciones, la Provincia procurará especialmente que las personas gocen de los siguientes derechos:

(...)

$\left.6^{\circ}\right)$ Las personas de la tercera edad serán protegidas adecuadamente para asegurar su permanencia en la vida social y cultural mediante el desarrollo de actividades útiles a sí mismas y a la sociedad".

Es una norma ciertamente abierta, pero que -aun así- parece dejar de lado ámbitos en los que el adulto mayor necesita ser tutelado jurídicamente. Empero, viene a salvar ese defecto el interesante artículo 24, que en su primer párrafo es cláusula de "derechos no enumerados" (estableciendo que "los habitantes de la Provincia, como habitantes de la Nación Argentina, y al amparo de la Constitución Nacional, tienen todos los derechos que aquélla establece, sin negación ni mengua de otros derechos no enumerados o virtualmente retenidos por el pueblo"), mientras que en los otros dos

(67) Texto según la reforma sancionada el 6 de junio de 2006. 


\section{La ancianidad en el Derecho Constitucional argentino Old age in Argentine Constitutional Law}

destaca la obligación estatal de tomar acciones concretas en pos de la igualdad de oportunidades, y expresamente exige la promoción del pleno goce de los derechos constitucionales de los ancianos, así como de los establecidos en convenciones internacionales de derechos humanos. En adición, determina como regla la operatividad de los derechos consagrados en estas últimas, avanzando en una tendencia que-como hemos expresado a lo largo del presente estudio- consideramos sumamente encomiable(68).

\section{Conclusiones}

El tratamiento que las constituciones provinciales argentinas efectúan de los derechos de los ancianos resulta dispar, existiendo básicamente tres vertientes:

a) La primera está conformada por algunas cartas magnas que omiten todo pronunciamiento respecto de la vejez, y en las que esa carencia queda suplida, afortunadamente, mediante las "cláusulas de derechos no enumerados" que las mismas contienen.

b) La segunda, que en ciertas oportunidades complementa a la anterior, se integra de aquellas leyes supremas que sólo pautan explícitamente determinadas normas previsionales.

c) La tercera, característica de los ordenamientos más recientes, está dada por aquellos textos que, con mayor o menor detalle, enuncian los "derechos de los ancianos".

Sólo esta última tendencia, por ventura en expansión, reconoce a la persona mayor como sujeto de Derecho pleno, capaz de ejercer sus facultades a todo nivel pero asimismo merecedor de protección por parte de la comunidad.

En lo fundamental, se privilegian determinados derechos, mientras que otros quedan excluidos de las constituciones. Es mencionada reiteradamente la "integración económica y sociocultural", pero nada se dice sobre los medios de lograrla o promoverla. Algo similar sucede con la atención de la salud, tanto física como moral.

De todos modos, debe comprenderse que los respectivos constituyentes han buscado establecer lineamientos básicos, de forma tal que los poderes del Estado puedan ejecutar políticas, dictar leyes o ejercer la función jurisdiccional, con una visión cabal de la importancia que conlleva cuidar a las personas mayores. En tal sentido, resulta destacable que se ponga de resalto el deber de la familia de resguardar y contener al anciano, frente a las situaciones de desamparo que dolorosamente presenciamos en nuestros días. $Y$ es también acertado que se deje sentada la obligación estatal de actuar frente a la ausencia de parientes. Empero, preocupadas por señalar esta última responsabilidad, algunas leyes supremas omiten toda referencia a la formulación de proyectos sociales para la vejez como categoría totalizadora, abarcativa de seres con o sin grupo de pertenencia.

Pocas son las cartas magnas que realizan una enumeración exhaustiva de los derechos de la ancianidad, olvidando que en este caso puntual, lo que abunda no daña. Muy por el contrario, al consistir en especies de guías para administradores públicos, legisladores y magistrados, tienen por propósito primordial actuar como norte, más allá de la operatividad que efectivamente cobrarán frente a transgresiones concretas o requerimientos inminentes.

Numerosas constituciones reconocen al anciano el derecho al trabajo, a la vivienda

(68) Tales párrafos (segundo y tercero) del artículo 24, indican, en su parte pertinente: "El Estado Provincial deberá promover medidas de acción positiva y remover los obstáculos para garantizar la igualdad real de oportunidades y de trato, y el pleno goce y ejercicio de los derechos reconocidos por esta Constitución, la Constitución Nacional, y por los Tratados Internacionales vigentes sobre Derechos Humanos, en particular respecto de (...) ancianos. Los derechos y garantías consagrados por los Pactos y Tratados Internacionales sobre Derechos Humanos, incorporados como Ley de la Nación, son de carácter operativo, salvo en los supuestos en que expresamente se ha dejado sujeta su aplicación al dictado de una ley". 
Mariano Horacio Novelli

y a la jubilación. No obstante, son escasas las que hacen referencia a la tranquilidad, al goce de la cultura, al turismo y a la igualdad real de oportunidades. Nos permitimos marcar que ello no parece casualidad, sino más bien una causalidad producida por la idiosincrasia de la posmodernidad. Se concede prioridad a lo material, a la par que se deja de lado aquello que atañe a la espiritualidad del hombre.

A nuestro criterio, no sólo se trata de un error, sino de una circunstancia que, según los casos, puede inclusive dar por tierra con otros nobles postulados de los propios ordenamientos. No puede hacerse a la persona mayor auténtica partícipe de la vida social exclusivamente a través de derechos de contenido patrimonial, cuando tal cosa depende sobre todo de factores que superan por completo la faz económica y que corresponden a lo más profundo del ser.

En definitiva, la captación que las cartas constitucionales efectúan de los derechos de los ancianos es dispar. De allí que, con miras al porvenir, creamos indispensable que las sucesivas reformas adopten una idea más abierta y sensible, que asimile a este período vital como lo que, a pesar de vaivenes y complicaciones, generalmente es: un tiempo de serena y fecunda acción; de templanza y sabiduría; de prudencia y conocimiento indulgente.

Ha llegado la hora de comprender, de una vez y para siempre, que las normas relativas a los ancianos deben desprenderse de la realidad de éstos, ser idóneas para volver a insertarse adecuadamente en ella, e igualmente plasmar valores como el amor, la humanidad y la justicia.

\section{Referencias bibliográficas}

Alba, Víctor. 1992. Historia social de la vejez. Barcelona: Laertes.

Baeza, Carlos. 2000. Exégesis de la Constitución argentina. Buenos Aires: Ábaco de Rodolfo Depalma.

Biazzi, Ricardo. 1982. Provincia de Misiones: ¿Es viable su modelo constitucional?. La Constitución Provincial de 1958. Posadas: Facultad de Humanidades y Ciencias Sociales de la Universidad Nacional de Misiones.
Bidart, Germán. 1995. Tratado elemental de Derecho Constitucional Argentino, $1^{\text {a }}$ reimp. Buenos Aires: Ediar.

1998. Manual de la Constitución reformada, $1^{a}$ reimp. Buenos Aires: Ediar.

Bobbio, Norberto. 1997. De senectute, traducido por Esther Benítez. Madrid: Taurus.

Cassagne, Juan. 1998. Derecho Administrativo, $6^{a}$ ed. Buenos Aires: Abeledo-Perrot.

Ciuro, Miguel. 1992. "Derecho de la Ancianidad". Investigación y Docencia 20: 35-40.

1995. "Comparación jusfilosófica del Derecho de Menores y el Derecho de la Ancianidad". Investigación y Docencia 25: 7-11.

Convención Nacional Constituyente. 1949. Diario de Sesiones. Buenos Aires: Imprenta del Congreso de la Nación.

Dabove, María. 2001-2002. "Las fuentes formales del derecho de la ancianidad. Aportes de los Derechos Humanos y la Bioética a la construcción de su autonomía formal". Revista de la Facultad de Derecho de la Universidad Nacional de Rosario 16: 75-84.

2002. Los derechos de los ancianos, Buenos Aires - Madrid: Ciudad Argentina.

Epifanio, Hugo Raúl. 1982. La Constitución de Río Negro anotada. General Roca: Hugo Raúl Epifanio.

Frías, Pedro y otros. 1989. Las nuevas constituciones provinciales. Buenos Aires: Depalma.

Gafo, Javier, ed. 1995. Ética y Ancianidad. Madrid: Universidad Pontificia Comillas. 


\section{La ancianidad en el Derecho Constitucional argentino Old age in Argentine Constitutional Law}

Galetti, Amelia y Carlos Torressi. 1983. Constitución provincial de Santa Fe: principios dogmáticos y políticos. Una preceptiva provincial expresión de la preceptiva constitucional nacional y universal. Paraná: Centro de Investigaciones Históricas del Instituto Nacional de Enseñanza Superior.

García de Francile, Alicia. 1984. Los Derechos Individuales y Sociales en las Constituciones Provinciales Argentinas. San Juan: Facultad de Derecho y Ciencias Sociales de la Universidad Católica de Cuyo.

Gerosa Lewis, Ricardo Tomás. 2002. Análisis de la Constitución de la Provincia del Chubut, Esquel: Ricardo Tomás Gerosa Lewis.

Goldschmidt, Werner. 1987. Introducción filosófica al Derecho, $6^{\mathrm{a}}$ ed., $5^{\mathrm{a}}$ reimp. Buenos Aires: Depalma.

Gonem de Gandolfo, Graciela N. 1996. "Reflexiones sobre la condición de los ancianos en la actualidad". Boletín del Centro de Investigaciones de Filosofía Jurídica y Filosofía Social 21: 83 y siguientes.

Granjel, Luis. 1991. Historia de la vejez. Gerontología. Gerocultura. Geriatría. Salamanca: Universidad de Salamanca.

Heredia, José. 1995. La Reforma en la Provincia del Chubut. Puerto Madryn: Centro de Estudio e Investigaciones Patagónico.

Linares, Segundo. 1977. Tratado de la Ciencia del Derecho Constitucional, $2^{\mathrm{a}}$ ed. Buenos Aires: Plus Ultra.

López, Marcelo. 1997. Constitución de la Ciudad Autónoma de Buenos Aires comentada, Buenos Aires: Estudio.

Lopresti, Roberto. 1998. Constitución argentina comentada, $2^{\mathrm{a}}$ ed. Buenos Aires: Unilat.

Luciani, Fernando y Mariano Novelli. 2001. "El ciudadano como consumidor". Investigación y Docencia 34: 89-102.

Mayón, Carlos. 1995. Constitución de la Provincia de Buenos Aires, $4^{a}$ ed. Buenos Aires: Depalma.
Melo, Carlos. 1950. Constituciones de la Provincia de Córdoba. Córdoba: Dirección General de Publicidad de la Universidad Nacional de Córdoba.

Méndez, María. 1983. "Los ancianos en la legislación civil”. La Ley 1983-A: 312-322.

Minois, Georges. 1989. Historia de la vejez. De la Antigüedad al Renacimiento, traducido por Celia María Sánchez. Madrid: Nerea.

Morelli, Mariano. 1999. "Ética, Derecho y Ancianidad. Algunas cuestiones vinculadas con el concepto de ancianidad". Bioética y Bioderecho 4: 33-40.

Novelli, Mariano. 2005. "La función política de la Corte Suprema y el control judicial de constitucionalidad". Cartapacio de Derecho 8: 1-8, http://www.cartapacio.edu.ar/ojs/index. php/ctp/article/view/60/65.

2006a. "Los derechos constitucionales de los ancianos en Argentina". En Derecho de la Ancianidad. Perspectiva interdisciplinaria, dirigido por María Isolina Dabove Caramuto y Adolfo Prunotto Laborde. Rosario: Juris, 45-49.

2006b. Los derechos constitucionales de los ancianos en la Argentina. Buenos Aires, Dunken - Fundación para las Investigaciones Jurídicas.

Novelli, Mariano y Fernando Luciani. 2004. "Las decisiones judiciales y los factores de poder (Los postulados de Lassalle desde una perspectiva jurídica trialista)". Zeus 94: 133-142.

Novelli, Mariano y otros. 2008. "Aportes para el pleno reconocimiento constitucional de los derechos de los ancianos". La Ley 2008-D: 751-762. 


\section{Mariano Horacio Novelli}

Ortiz, Miguel, Esther Borgarello y Susana Aguirre. 1994. Las constituciones provinciales. Córdoba: Marcos Lerner.

Pérez, Dardo. 1999. Constitución de la Nación Argentina, $23^{\mathrm{a}}$ ed. Buenos Aires: Depalma.

Quiroga, Humberto. 1995. Constitución de la Provincia de Buenos Aires. Comentario a las reformas y notas de jurisprudencia, Santa Fe: Rubinzal-Culzoni.

1996. Constitución de la Ciudad de Buenos Aires comentada, Santa Fe: RubinzalCulzoni.

Ramella, Pablo. 1986. "La Constitución de San Juan”. La Ley 1986-D: 846-850.
Sabsay, Daniel y José Onaindia. 1997. La Constitución de los Porteños. Análisis y comentario. Buenos Aires: Errepar.

2000. La Constitución de los Argentinos. Análisis y comentario de su texto luego de la reforma de $1994,5^{\mathrm{a}}$ ed. Buenos Aires: Errepar.

Sagrera, Martín. 1992. El edadismo. Contra "jóvenes" y "viejos". La discriminación universal. Madrid: Fundamentos.

Sagüés, Néstor. 1997. Elementos de derecho constitucional, $2^{\mathrm{a}}$ ed. Buenos Aires: Astrea.

Scotti, Edgardo. 1995. Comentarios a la reforma de la Constitución de la Provincia de Buenos Aires. La Plata: Libros Jurídicos.

Tomasello, Andrés. 2002. "Derechos de la ancianidad". Doctrina Judicial 2002-3: 928-941. 